\title{
Constitutional Limbo in Trinidad AND Tobago (THE UNCERTAINTY, NOT THE DANCE)*
}

\author{
Gregory Tardi
}

\section{INTRODUCTION}

Constitutional practice in Westminster-style parliamentary democracies throughout the Commonwealth can produce an infinite variety of scenarios of political law. In recent years, few such scenarios could have proved more intricate and intractable than the constitutional crisis that ended a short time ago in Trinidad and Tobago. A Canadian lawyer seeking to understand these difficulties would be navigating through instruments and practices not unfamiliar by comparison to his or her own system.

\section{TRINIDAD AND TOBAGO'S POLITICAL LEGAL CULTURE}

Trinidad and Tobago acceded to independence in the manner of a Dominion with a governor general in 1962 . The country adopted a republican form of government in 1976. August 1 of that year also saw the genesis of its current Constitution. ${ }^{1}$ There are fundamental grounds of comparison between Trinidad and Tobago's Constitution and Canada's Constitution Act, $1982,{ }^{2}$ in particular as to the supremacy of law in the governmental systems of the two countries. The preamble in both instruments adopts the principle of the rule of law as one of the foundations of democracy. Moreover, section 2 of the Trinidad and Tobago Constitution, which enshrines the Constitution itself as the supreme law, voiding any other law to

* The author gratefully acknowledges the advice of Professor Dr. Radhakrishnan Persaud, School of Social Studies, York University.

Constitution of the Republic of Trinidad and Tobago, No. 4 (1976) [Constitution].

2 Constitution Act, 1982, being Schedule B to the Canada Act 1982 (U.K.), 1982, c.11, online: Canlii <http://www.canlii. org/ca/const_en/const1982.html $>$ [Constitution Act, 1982]. the extent of any inconsistency, can be considered the counterpart to section 52(1) of Canada's Constitution Act, 1982. Trinidad and Tobago goes one step further in assuring not only that the political regime is based on law, but also that legal considerations are adequately represented within the government. There is a fundamental requirement, set out in section 72(2) of the Constitution, that one of the ministers in the cabinet must be the attorney general; without an attorney general, no government is complete.

Political life reflects the twin-island nation's ethnic composition. Some 39.5 percent of the population is of African origin. ${ }^{3}$ The principal political party of this community is the People's National Movement Party (PNM), led by Patrick Manning. Roughly another 40.3 percent of the people are of East Indian descent. ${ }^{4}$ The United National Congress Party (UNC), led by Basdeo Panday, captures the political preferences of this segment of the population. The bases of political culture in Trinidad and Tobago are primarily ethnic and racial. Roughly equal parts of the population and of the electorate adhere to race-based party loyalties. This results in a combination of polarization and racial tension, which make both public life in general, and voting behaviour in particular, divisive.

Parliament comprises two elected houses. The lower house, called the House of Representatives, is comparable to the Canadian House of Commons. The Upper House is styled the Senate; it is comprised of thirty-one members. General elections to the House of Representatives were held in

\footnotetext{
"People: Trinidad and Tobago," online: The World Factbook $<$ http://www.cia.gov.cia/publications/factbook/geos/td.html\# People $>$.

Ibid.
} 
December 2000, in which the UNC won with nineteen seats to the PNM's sixteen, with one seat going to a smaller party. Basdeo Panday became prime minister. In October 2001, three members of the UNC government defected, resulting in an unsustainable minority. The origin of the constitutional crisis, which gripped Trinidad and Tobago for most of 2002, was the general election of 10 December 2001, held as a result of the collapse of the previous government.

\section{A UNIQUE ELECTION RESULT, IN CONTEXT}

The 2001 general election produced a result that, prima facie, was not entirely unusual among democracies. Overall throughout the country, the UNC polled 49.7 percent of the votes, while the PNM obtained 46.3 percent. $^{5}$ The almost-even division of the electorate among competing political formations seems to have become somewhat commonplace. This was true in the Québec referendum of 1995; in several U.S. states, notably Florida, in the presidential election of 2000; in some of the elections held at various times during the last few years in France and Israel; and, during 2000, in Hungary and Germany. The particularity of the 2001 election in Trinidad and Tobago was that the distribution of the votes through the first-past-the-post electoral system into thirty-six single-member constituencies produced a dead heat: eighteen seats for each party. Thus, the stage was set in a most direct manner for a parliamentary and governmental deadlock. The events following the general election unmistakeably demonstrate the institutional dangers inherent in having an even number of seats in a legislative body. This is particularly so when the communities forming the population itself are so evenly split.

The subject matter of an election result that, whether directly or indirectly, produces a situation in the legislative body that is susceptible to deadlock, is apt for comparison with recent events in Canada. The Province of New Brunswick held general elections on 9 June 2003 for the

\footnotetext{
"Elections in Trinidad and Tobago: 2001 General Elections," online: Wikipedia: The Free Encyclopedia <http://en wikipedia.org/wiki/Elections_in_Trinidad_and_Tobago\# 2001_General_Elections>.
}

Legislative Assembly, which consists of fifty-five seats. With an odd number of constituencies, observers would think it unlikely that an evenly split House could arise out of the election. Less directly than in Trinidad and Tobago, however, that is what has occurred. The Progressive Conservative Party obtained twenty-eight seats and the Liberal Party retained twenty-six seats, while the New Democratic Party elected one member. The House met on 29 July 2003 with a government bench of twenty-eight seats and the combined opposition parties holding twenty-seven seats. If any member of the governing party became Speaker, the House would become evenly split, with twenty-seven MLAs facing each other on either side in every debate and every vote. Despite this danger, the House did choose a Speaker on 29 July 2003 from among the Progressive Conservative members. Until the House rose on 8 August 2003, its business proceeded. Nevertheless, it seems likely that the current Legislature will be short-lived if the government and the combined opposition do not find some democratic accommodation mechanism.

\section{CONSTITUTING A GOVERNMENT}

In this circumstance, the first constitutional question that Trinidad and Tobago had to address was who would be asked to form the government? Pursuant to section 76(1) of the Constitution, the president is to appoint as prime minister either the leader of the party that commands the support of the majority of members in the House of Representatives or, where there is no undisputed leader or majority party, the member most likely to command a majority. This is, essentially, a codification of the similar practice prevalent in Canada. On 24 December 2001, President Arthur Robinson exercised his discretion under section 76(1)(b) of the Constitution and invited Patrick Manning of the PNM to form a government, despite the fact that the UNC had received 3.4 percent more of the votes in the country at large. It was reported that the two parties had had an earlier agreement that they would accept the President's choice, but any such understanding broke down. Neither a power-sharing scheme nor a government of national unity could be worked out. The parties likely continued discussions quietly for several months, but these bore no fruit. 
How would such a situation have been handled in Canada? No Canadian governor general has ever needed to address the issue of which party leader to invite to form a government immediately after a general election; the results in our general elections have never been that close. It is possible, however, to construct a legal analogy, albeit a somewhat strained one. On 27 February 1996, the Speaker of the House of Commons had to rule on a point of privilege as to whether the Bloc Québécois should continue as Official Opposition or give way to the Reform Party. As part of the ruling that allowed the Bloc to continue in the role of opposition, the Speaker held that the number of seats obtained by a party in the House should carry greater weight than the popular vote. Using this principle, the Trinidadian President may have been justified in disregarding the popular vote and in basing the judicious application of his discretion on other grounds. In the present instance, he chose not to apply the principle of continuity either, transferring governmental authority from the UNC, which had held it after the 2000 elections, to the PNM. The considered assumption is that the President must have believed Mr. Manning had a better chance of forming a viable government, despite the fact that there would be a change of ruling party and that the UNC had polled more votes than the PNM.

Trinidad and Tobago's newly installed Prime Minister constituted a cabinet in accordance with sections 76(3) and 79 of the Constitution, which, respectively, mandate the appointment of ministers and the attribution of portfolios to them. In the country's Westminster-style system of governance, the proper path should have been to open the House of Representatives for legislative business by electing a Speaker and then, in order to govern constitutionally, for the incoming government to meet the House and seek its confidence.

\section{OPENING THE EVENLY SPLIT PARLIAMENT}

The Constitution mandated a schedule for the government to meet the House. Subsection 67(2) provided not only that there be a session of each House once in every year, but also that a period of six months should not intervene between the last sitting of Parliament in one session and the first sitting thereof in the next session. Canadian constitutionalists will be reminded of section 5 of their own Constitution Act, 1982, which indicates that there shall be a sitting of Parliament at least once every twelve months. The Sixth Parliament of Trinidad having been dissolved in October 2001, section 67(2) could be read as meaning that the Seventh Parliament was required to be convened no later than April 2002. Even if section 67(2) is more properly interpreted as imposing a timetable within the life of a single Parliament, a lapse of four months after the general election should have been sufficient for the government to meet the House.

\section{THE HEART OF THE MATTER: ELECTING A SPEAKER}

Parliament was, in fact, convened on 5 April 2002. It was at this juncture that the second constitutional question flowing from the 2001 general elections arose. Pursuant to section 50 of the Constitution, when the House of Representatives first meets after a general election and before it proceeds to the despatch of any other business, it shall elect a Speaker. Subsection 3(1) of the Standing Orders of the House of Representatives reinforces this constitutional requirement in almost identical language. It should be noted that the Canadian House of Commons attributes similar primordial importance to the installation of a Speaker. Section 44 of the Constitution Act, $1867^{6}$ requires that the House of Commons, in its first assembly after a general election, proceed with all practicable speed to elect one of its members to be Speaker. Section 2 of the Standing Orders of the House of Commons in Trinidad and Tobago also declares that, at the opening of the first session of a Parliament, the election of a Speaker shall be the first order of business. The election of a Speaker takes precedence over all other parliamentary business in both countries.

In the circumstances of having an absolute equality of seats in the House of Representatives, neither political party wanted to give up a member who would vote along partisan lines so that he or

Constitution Act, 1867 (U.K.), 30 \& 31 Vict., c. 3, s.44 (reprinted in R.S.C. 1985, App. II, No. 5). 
she would serve as Speaker. The political cleavages in Trinidad and Tobago's political society prevented any legislator from crossing the floor of the House. The Constitution did, however, provide a mechanism to circumvent such a difficulty. Subsections 50(2) and (3) authorize that a person who is not a member of the House of Representatives and who is not in the Senate may be elected Speaker of the House of Representatives, provided he or she is a citizen and is not disqualified for election to the House of Representatives. This, of course, is in sharp contrast to Canadian practice. The closest the House of Commons has come to such a scheme was in 1979, when, upon a change of government, James Jerome, the previously serving Speaker was re-appointed by the incoming administration. (In those days, in Canada, the Speaker was not yet elected.)

By the time the House of Representatives met on 5 April 2002, it was clear that none of the parliamentarians elected in December 2001 would be coaxed into the Speaker's chair or pried loose from the party loyalty which was dividing the country. The First Session of the Seventh Parliament was thus invited to consider a former principal of the St. Augustine campus of the University of the West Indies for the mantle of the speakership. The vote on this proposal produced eighteen "ayes" and eighteen "noes." There was some question as to whether an equal split meant that the proposal had been accepted or defeated, but the clerk of the House ruled that the proposal had been defeated. The proceedings continued in an atmosphere of rancour over the course of April 5 and 6 . The House was asked to consider no less than fifteen notables from Trinidad and Tobago society for the position of Speaker. ${ }^{7}$ Every candidate was voted down either on an 18-18 split or on a 36-0 vote.

At the end of the second day of the session, the clerk sought the view of the House as to how to proceed, believing that the search for a Speaker would continue after inter-party consultations. However, the parliamentary deadlock was

Incidentally, one of them was a graduate of McGill and Queen's universities. Dr. Marjorie Thorpe, M.A. 1963 (McGill) and Ph.D. 1975 (Queen's), is now Dean of the Faculty of Arts and General Studies, University of the West Indies, St. Augustine Campus. complete and the country's constitutional and political life was paralyzed. Given that pursuant to section 53 of the Constitution, Parliament's function is to make laws for the peace, order, and good government of the country, we may be entitled to question whether, in the absence of a Speaker to guide the legislative process, there was in fact a functioning House of Representatives at all. In any event, the formula of section 53 is one that Canadian lawyers will recognize from section 91 of their own Constitution Act, 1867. We should also note that in the absence of a Speaker, the government would not be able to present its Speech from the Throne, nor, eventually, its budget before the House. Following the requirements of Chapter 8 of the Constitution, dealing with the finances of the state, the government had to have a 2002/2003 budget in place by October 2002, when the previous estimates would run out.

In these circumstances, the UNC was, by then, militating for another election. Meanwhile, the timetable imposed by section 67(2) of the Constitution for the sessions and sittings of Parliament continued to apply.

The scenario that had developed, in which the legislature could not function because it was incapable of electing a Speaker, has never materialized at the federal level in Canada. It is not entirely unknown in Canadian practice, however. That is precisely what happened in Prince Edward Island in 1859 and in Newfoundland in 1909. Using the expression of Professor Andrew Heard, when an election produces a legislature that simply cannot function, fresh elections are an absolute necessity. ${ }^{8}$

It will remain an unresolved quandary whether the proceedings of April 5 and 6 actually amounted to a Session of Parliament, but the government decided to treat them as such. On 22 August 2002, the president reconvened Parliament for what was being entitled the Second Session, to begin August 28. At the outset of this renewed gathering, however it should be characterized, the UNC opposition registered its view that what it called the "sitting" was unconstitutional and that

Andrew Heard, Canadian Constiutional Conventions: The Marriage of Law and Politics (Toronto: Oxford University Press, 1991) at 23 
it was participating under objection. Notwithstanding, the clerk again attempted to have a Speaker elected. This time, only two further candidacies were considered. The first was defeated in an 18-18 split and the second in a 36-0 vote. Thereupon, the Prime Minister proposed to advise the President to dissolve Parliament and to seek a third general election within three years. The clerk acknowledged that, although no formal votes could be taken in the House apart from the election of a Speaker, the House would agree that there is no need to continue what she also called "this sitting" any further. The entire proceeding of 28 August 2002 took only thirteen minutes. Later that day, the President, using his power under section 68(1) of the Constitution, dissolved the Parliament that, in essence, had never been sufficiently constituted to commence functioning properly.

\section{CUTTING THE GORDIAN KNOT}

The general elections resulting from the inability of the Seventh Parliament to function was held on 7 October 2002. There was genuine anxiety in Trinidad and Tobago's political community that these elections would return another House with an 18-18 split among seats going to the PNM and the UNC. The electorate comprised 875,260 people and the voter turnout of 608,830 was substantial. ${ }^{9}$ In the end, the PNM was returned in twenty seats while the UNC secured sixteen seats. The media expressed the country's satisfaction not so much with the result as with the fact that the crisis had ended. Trinidad and Tobago's political life could function anew.

The Elections and Boundaries Commission certified the election results promptly and, on 9 October 2002, Patrick Manning, leader of the PMN, was sworn in as Prime Minister. In an interesting twist, Manning was not able to complete the process of establishing his government for some time because he delayed filling the constitutionally vital portfolio of attorney general. Unburdened in the Eighth Parliament with the kinds defections that occurred during the Sixth, Prime Minister Manning has

\footnotetext{
9 "PNM Wins" The Trinidad Guardian (8 October 2002); and "PNM Returns to Power in Trinidad and Tobago" Voice of America Press Releases and Documents (8 October 2002).
}

been able to govern effectively.

\section{LESSONS FOR DEMOCRATIC CONSTITUTIONALISM}

Apart from the inherent benefit Canadian constitutionalists can draw from expanding their perspective by comparing their country's political legal system to that of a partner in the Commonwealth, which receives scarce media coverage and analysis in Canada, what lessons can we draw from Trinidad and Tobago's recent experience? The first and most significant point is that in democratic constitutional regimes where the constitution itself professes adherence to the rule of law, the national or public interest in legality and legitimacy requires, on the part of political parties as well as parliamentarians, a degree of moderation and self-restraint. Good governance - the constitutional standard inherited by both Canada and Trinidad and Tobago from the Westminster tradition - requires that unbridled and excessive political partisanship be tempered by respect for legality, including constitutional conventions. Applying this democratic principle to the present instance, the parties in Trinidad and Tobago might well have put to good use the opportunity provided by the Constitution to agree on installing a Speaker from outside Parliament, an option the Canadian system does not offer. While this proposition is subject to criticism from those with a stake in the system, it does appear to have been the least disruptive of the options that were available to the Parliament of Trinidad and Tobago.

Such advice is much easier to impart in one's capacity as an observer or scholar of political legal practice, and it is even easier for an outsider to offer, than for an involved practitioner of the political arts. Nevertheless, for a country to acknowledge the full implications of the rule of law, the political class might be well advised to seek some accommodation in the name of constitutionalism as being preferable to renewed resort to the political weapon of unending electioneering. Democracy implies giving constitu-tional legal procedures the opportunity to function.

Going beyond this, in respect of the 
machinery of government, the designers of electoral systems should avoid composing parliamentary bodies with an even number of seats. They may also consider elements of proportional representation that can serve to mitigate the distorting effects of the first-past-thepost method of voting.

\section{Gregory Tardi, BA (Hons.), B.C.L, LL.B}

Senior Legal Counsel, Legal Services

House of Commons, Parliament of Canada

TardiG@parl.gc.ca

The views expressed here are exclusively those of the author and are entirely non-partisan. This article was prepared as a scholarly paper, not on behalf of the House of Commons, its members, or its administration. 